“Vol 3, No 1 (2019): July - Desember”

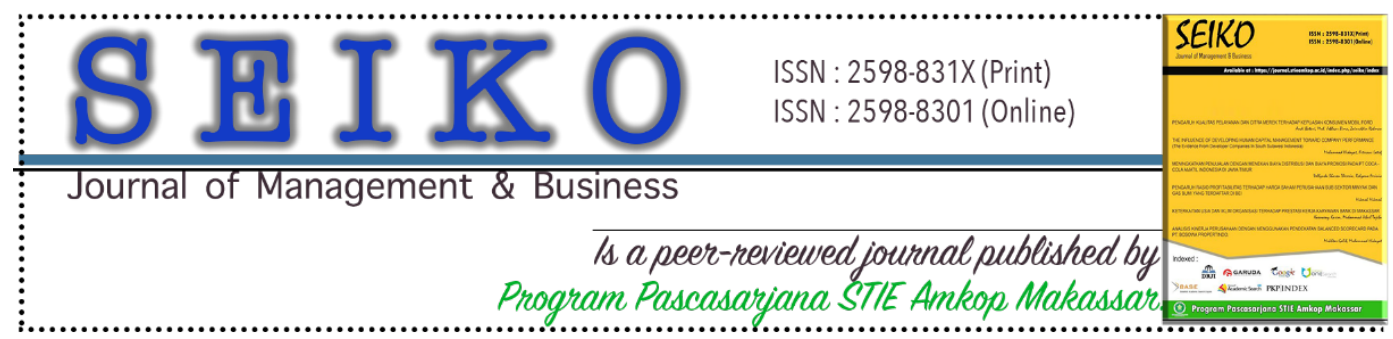

How to Cite:

M.Sujai. (2019). ANALISIS PENGELOLAAN NON PERFORMING LOAN PT.BANK TABUNGAN PENSIUNAN NASIONAL,TBK MITRA USAHA RAKYAT KANTOR CABANG PEMBANTU TOLITOLI. SEIKO : Journal of Management \& Business, 3(1), 1 - 12.

\title{
ANALISIS PENGELOLAAN NON PERFORMING LOAN PT.BANK TABUNGAN PENSIUNAN NASIONAL,Tbk MITRA USAHA RAKYAT KANTOR CABANG PEMBANTU TOLITOLI
}

\section{Analysis of non Performing Loan Management PT. Bank Tabungan Pensiunan Nasional, Tbk Mitra Usaha Rakyat Tolitoli Sub-Branch Office}

\author{
MUHAMMAD SUJAI \\ STIE Mujahidin Tolitoli \\ Email : $\underline{\text { moh.sujai@stiemujahidin.ac.id }}$ \\ SINCE RUWAU \\ STIE Mujahidin Tolitoli \\ Email : since5660ruwau@gmail.com
}


“Vol 3, No 1 (2019): July - Desember”

\begin{abstract}
ABSTRAK
Penelitian ini mengkaji tentang pengelolaan Non Performing Loan dari segmen kredit usaha pada suatu lembaga bank. Penelitian ini dilakukan pada PT. Bank Tabungan Pensiunan Nasional,Tbk Mitra Usaha Rakyat Kantor Cabang Pembantu Tolitoli dengan alamat Jl.Usman Binol Kelurahan Baru Kecamatan Baolan Kabupaten Tolitoli. Metode penelitian yang digunakan dalam penelitian ini adalah metode Penelitian deskriptif. Alat analisis dalam penelitian ini adalah rasio Non Performing Loan (NPL), yaitu rasio yang menggambarkan tingkat persentase tertentu antara jumlah kredit bermasalah yaitu kredit kurang lancar, kredit diragukan dan kredit macet dibandingkan dengan total Nkredit yang diberikan.

Hasil perhitungan rasio NPL dari beberapa tahun penelitian ini membuktikan bahwa pengeloaan Non Performing Loan pada PT. Bank Tabungan Pensiunan Nasional, Tbk Mitra Usaha Rakyat Kantor Cabang Pembantu Tolitoli telah efektif. Standar pengukuran efektifnya pengelolaan Non Performing Loan pada bank bersangkutan ini adalah besarnya persentase Non Performing Loan PT. Bank Tabungan Pensiunan Nasional, Tbk Mitra Usaha Rakyat Kantor Cabang Pembantu Tolitoli yang tetap berada dibawah atau kurang dari (<) 5\%, sesuai dengan Kriteria Penetapan Peringkat Profil Risiko ditinjau dari kualitas Non Performing Loan untuk kategori bank yang sehat, berdasarkan peraturan perbankan yang tertuang dalam Surat Edaran Bank Indonesia (SEBI) No. 6/23/DPNP tanggal 31 Mei 2004. Proses pengumpulan data yang dilakukan dalam penelitian ini dilakukan dengan cara observasi, wawancara dan studi

pustaka.
\end{abstract}

Kata kunci : Pengelolaan, Non Performing Loan, Kredit Usaha

\begin{abstract}
This study examines the management of Non-Performing Loans from the business loan segment at a bank institution. This research was conducted at PT. Bank Tabungan Pensiunan Nasional, Tbk Mitra Usaha Rakyat Tolitoli Sub-Branch Office, with the address Jl.Usman Binol, Kelurahan Baru, Baolan Subdistrict, Tolitoli Regency.

The research method used in this research is descriptive research method. The analytical tool in this study is the Non Performing Loan (NPL) ratio, which is a ratio that describes a certain percentage level between the number of problem loans, namely substandard loans, doubtful loans and bad loans compared to the total Nkredit given. The results of NPL ratio calculations from several years of this study prove that the management of Non Performing Loans at PT. Bank Tabungan Pensiunan Nasional, Tbk Mitra Usaha Rakyat Tolitoli Sub-Branch Office has been effective. The standard measurement of the effectiveness of the management of Non Performing Loans at this bank is the large percentage of Non Performing Loans of PT. Bank Tabungan Pensiunan Nasional, Tbk Mitra Usaha Rakyat Tolitoli Sub-
\end{abstract}


Branch Office, which remains below or less than $(<) 5 \%$, according to the Risk Profile Rating Criteria in terms of Non-Performing Loan quality for a healthy bank category, based on banking regulations stated in Bank Indonesia Circular Letter (SEBI) No. 6/23 / DPNP dated May 31, 2004. The data collection process in this research was carried out by observation, interview and study library.

Keywords: Management, Non Performing Loans, Business Loans

\section{PENDAHULUAN}

Peranan bank dalam perekonomian secara garis besar terdiri dari 2 (Dua) yaitu menghimpun dana dari masyarakat (funding), serta menyalurkan dana kepada masyarakat (lending). Lembaga perbankan merupakan lembaga yang ditunjuk langsung oleh pemerintah secara resmi sebagai penyimpanan kekayaan masyarakat dan sebagai pihak penyelenggara kredit. Dengan demikian lembaga perbankan memiliki pengaruh sangat besar, penting dan strategis dalam upaya menggerakkan perekonomian dan menunjang pelaksanaan pembangunan nasional.

Pentingnya kredit dalam operasi suatu bank menuntut bank tersebut agar selalu menjaga margin kredit dengan sangat baik. Oleh karena itu diperlukan pengelolaan kredit yang efektif dan efisien. Bank adalah bisnis. Bisnis yang berdagang dalam kredit dan uang. Usaha yang paling memberikan kontribusi terbesar bagi bank adalah penyaluran kreditnya, sehingga penyaluran kredit menjadi aktivitas utama dunia perbankan. Sumber penghasilan terbesar bank yang berasal dari kredit yang disalurkan kepada masyarakat juga merupakan sumber resiko terbesar suatu bank. Resiko tersebut adalah resiko kegagalan kredit atau kredit bermasalah. Kredit bermasalah yaitu keterlambatan / kegagalan debitur dalam mengembalikan pinjamannya yaitu pinjaman pokok dan bunga pinjamannya sesuai dengan perjanjian/kesepakatan antara debitur dengan pihak bank. Rasio yang digunakan untuk mengukur kredit bermasalah ini disebut rasio Non Performing Loan (NPL). Rasio Non Performing Loan (NPL) adalah rasio yang menggambarkan persentase tertentu antara jumlah kredit bermasalah (kredit kurang lancar, kredit diragukan dan kredit macet) dengan total kredit yang diberikan. Bank Indonesia 


\section{"Vol 3, No 1 (2019): July - Desember"}

selaku Bank Sentral dalam Peraturan Bank Indonesia No.6/10/PBI/2004 tanggal 12 April 2004 telah menetapkan batas maksimal Non Performing Loan (NPL) untuk semua bank yang ada di Indonesia yaitu sebesar $5 \%$. Bank yang persentase NPLnya berada dibawah $5 \%$ dikategorikan sebagai bank yang sehat dan likuid, sebaliknya bank dengan persentase NPL yang lebih dari 5\% dikategorikan sebagai bank yang tidak sehat dan terancam likuidasi. Setiap bank dalam industri perbankan selalu menghadapi resiko perbankan, yang salah satunya adalah resiko kredit bermasalah (Non Peforming Loan), dikarenakan fungsi pokok bank yang adalah sebagai lembaga perantara keuangan (Financial intermediary). Berkaitan dengan resiko kredit bermasalah atau Non Performing Loan yang tidak akan pernah bisa dihindari oleh lembaga perbankan, sehingga dapat dikatakan bahwa hampir tidak ada bank yang tidak mengalami yang namanya kredit bermasalah ini. Tekanan kredit bermasalah atau Non Performing Loan membayangi kinerja perbankan sejak tahun 2013 sampai menjelang akhir tahun 2016 . Kinerja industri perbankan nasional pada tahun 2016 benar-benar terpuruk. Pada akhir tahun 2016, posisi outstanding kredit perbankan nasional hanya sebesar Rp. 4.377,2 Triliun, dibandingkan akhir tahun 2015 dimana outstanding kredit senilai Rp. 4.057,9 Triliun. Pertumbuhan kredit hanya terjadi 7,87\% dari tahun 2015. Industri perbankanpun mencatat rekor buruk baru pada tahun 2016 ini. Dikatakan rekor buruk sebab pertumbuhan kredit sebesar 7,87\% merupakan laju tahunan kredit yang terendah sejak era reformasi. Bahkan masih lebih buruk dibandingkan pertumbuhan kredit tahun 2009 lalu tatkala perekonomian global dan domestik dilanda krisis finansial terparah setelah krisis tahun 1997 lampau. Lesunya kinerja perbankan dalam penyaluran kredit ini tidak terlepas dari lemahnya perekonomian domestik dan global.

Non Performing Loan atau kredit bermasalah merupakan salah satu persoalan yang paling ditakuti oleh dunia perbankan, sebab NPL berpotensi menimbulkan kerugian bank. Suatu waktu, NPL memang bisa dipulihkan melalui restrukturisasi kredit atau bahkan eksekusi jaminan. Namun, pada prakteknya, selama proses pemulihan tersebut, bank juga tetap harus menyisihkan cadangan kerugian untuk menghapus NPL-NPL tersebut dari buku bank. Semakin banyak 


\section{"Vol 3, No 1 (2019): July - Desember"}

NPL, semakin tinggi pula nilai pencadangan yang harus disisihkan bank. Apabila bank mampu menekan besarnya persentase NPL, maka sudah tentu potensi keuntungan yang diperoleh bank akan semakin besar, karena adanya penghematan dana yang diperlukan bank untuk membentuk cadangan kerugian kredit bermasalah atau Penyisihan Penghapusan Aktiva Produktif (PPAP) tersebut. Penyisihan cadangan kerugian yang semakin besar bisa dipastikan akan menguras laba bank pada tahun berjalan. Penurunan laba yang signifikan tidak hanya akan membuat harga saham bank bersangkutan jatuh, tetapi kerap pula berujung pada pemecatan dewan direksi bank bersangkutan. Inilah yang ditakutkan manajemen bank. Persoalan NPL inilah yang mendorong manajemen industri perbankan semakin meningkatkan kehati-hatiannya menyalurkan kredit, sehingga setiap permohonan kredit yang masuk benar-benar akan disaring melalui proses verivikasi kredit yang detail dan panjang, dengan maksud mencegah kemungkinan terjadinya kredit bermasalah. PT. Bank Tabungan Pensiunan Nasional, Tbk telah mempublikasikan Laporan Keuangan 2016 (Full Year). Dari laporan tersebut diketahui bahwa PT. Bank Tabungan Pensiunan Nasional, Tbk tetap mampu mencetak pertumbuhan kinerjanya meskipun situasi ekonomi tahun 2016 menghadapi banyak tantangan. Tercatat hingga akhir Desember 2016, penyaluran kreditnya tumbuh 7,8 \% (Year on Year) dari Rp. 58,6 Triliun pada akhir Desember 2015 menjadi Rp.63,2 Triliun diakhir tahun 2016. Penyaluran kredit tetap diimbangi asas kehati-hatian yang tercermin dari rendahnya tingkat rasio kredit bermasalah (Non Performing Loan) yaitu sebesar 0,79 \%. NPL 0,79\% ini adalah persentase NPL yang terendah yang dicapai bank bersangkutan diantara semua bank dalam industri perbankan tanah air di tahun 2016. Seiring dengan pencapaian kinerja PT. Bank Tabungan Pensiunan Nasional, Tbk tersebut, total aset bank bersangkutanpun naik dari 12,7\% yaitu dari Rp.81 Triliun pada Desember 2015 menjadi Rp.91,4 Triliun pada akhir Desember 2016. Laba bersih setelah pajak (Net Profit After Tax-NPAT) juga mengalami peningkatan yaitu 3\% sehingga menjadi Rp. 1,75 Triliun. Pencapaian tersebut berujung pada kesimpulan Dewan Komisaris bank tersebut bahwa Direksi PT. Bank Tabungan Pensiunan Nasional, Tbk telah berhasil meraih kinerja yang memuaskan ditahun 2016. 


\section{"Vol 3, No 1 (2019): July - Desember"}

Salah satu cabang PT. Bank Tabungan Pensiunan Nasional, Tbk yang berkedudukan diarea Sulawesi Tengah yaitu PT. Bank Tabungan Pensiunan Nasional,Tbk Kantor Cabang Pembantu Tolitoli, menyalurkan kredit usaha dengan nama produk Mitra Usaha Rakyat (MUR), yang diberikan kepada debitur yang mengajukan permohonan kredit usaha. Seperti telah dijelaskan sebelumnya bahwa hampir tidak ada bank yang tidak mengalami yang namanya kredit bermasalah (Non Performing Loan), demikian juga dengan PT. Bank Tabungan Pensiunan Nasional, Tbk Kantor Cabang Pembantu Tolitoli. Tetapi dalam perjalanannya dari tahun 2011 sampai dengan 2016, bank bersangkutan terus berusaha menekan persentase NPL nya untuk tetap berada dibawah standar Peraturan Bank Indonesia, dengan mengupayakan pengelolaan kredit yang efektif sehingga dapat menekan persentase $N P L$ tidak mengalami peningkatan.

\section{KAJIAN PUSTAKA}

\section{Pengertian Bank}

Dalam pembicaraan sehari-hari bank dikenal sebagai lembaga keuangan yang kegiatan utamanya menerima simpanan dari masyarakat serta menyalurkan dana kepada masyarakat dalam bentuk pinjaman / kredit bagi masyarakat yang membutuhkan. Bank juga dikenal sebagai tempat untuk menukar uang, menerima atau memindahkan uang, serta melayani segala macam bentuk pembayaran dan setoran seperti pembayaran pajak, listrik, air, telefon, pembayaran uang kuliah dan pembayaran-pembayaran lainnya. (Julius, 2011). Definisi atau batasan mengenai bank pada dasarnya tidak berbeda satu dengan yang lain, kalaupun ada perbedaan hanya pada tugas dan jenis usaha bank bersangkutan. Menurut Prof. G.M. Verryn Stuart, Bank adalah suatu badan yang bertujuan untuk memuaskan kebutuhan kredit, baik dengan alat - alat pembayaran sendiri atau dengan uang yang diperolehnya dari orang lain manapun dengan jalan memperedarkan alat - alat penukar dan uang giral". (Malayu Hasibuan, 2011) 


\section{a. Fungsi dan Peran Bank}

Menurut Sigit Triandaru \& Totok Budisantoso (2012), fungsi utama bank adalah menghimpun dana dari masyarakat dan menyalurkannya kembali kepada masyarakat untuk berbagai tujuan atau bank sebagai perantara keuangan (financial intermediary). Secara spesifik fungsi bank adalah sebagai berikut Agent of trust, Dasar utama kegiatan perbankan adalah kepercayaan. Masyarakat bersedia menitipkan dananya dibank atas dasar kepercayaan masyarakat pada bank. Demikian halnya bank juga menyalurkan dananya kepada masyarakat (debitur) dalam bentuk pinjaman / kredit atas dasar kepercayaan bank kepada debiturnya. Agent of development, Kegiatan bank berupa menghimpun dan menyalurkan dana dari dan kepada masyarakat memungkinkan masyarakat melakukan kegiatan investasi, kegiatan distribusi, serta kegiatan konsumsi barang dan jasa. Kelancaran dari kegiatan - kegiatan ini memberikan kontribusi besar bagi perekonomian nasional serta mendukung terlaksananya pembangunan nasional. Agent of services, Bank juga memberikan penawaran jasa lainnya, antara lain jasa pembayarang dan setoran, jasa pengiriman uang/transfer, penitipan barang berharga, pemberian jaminan bank, penyelesaian tagihan dan jasa-jasa bank lainnya.

\section{Pengertian Kredit}

Dalam bahasa sehari-hari kata kredit sering diartikan memperoleh barang dengan membayar dengan cicilan atau angsuran dikemudian hari atau memperoleh pinjaman uang yang pembayarannya dilakukan dikemudian hari dengan cicilam atau angsuran sesuai dengan perjanjian. Jadi, dapat diartikan bahwa kredit dapat berbentuk barang atau berbentuk uang. Baik kredit berbentuk barang maupun kredit berbentuk uang, dalam hal pembayaran adalah dengan menggunakan metode angsuran atau cicilan tertentu. Kredit dalam bentuk uang disebut pinjaman. Menurut Undang-Undang Perbankan No.10 Tahun 1998, kredit adalah penyediaan uang atau tagihan yang dapat dipersamakan dengan itu, berdasarkan persetujuan atau kesepakatan pinjam meminjam antara bank dengan pihak lain yang mewajibkan pihak peminjam melunasi utangnya setelah jangka waktu tertentu dengan pemberian bunga. (Kasmir, 2014) 


\section{"Vol 3, No 1 (2019): July - Desember"}

\section{a. Unsur - Unsur Kredit}

Dari pengertian kredit secara utuh mengandung makna apa saja yang ada didalam kredit, sehingga jika kita bicara kredit, maka termasuk membicarakan unsur-unsur yang ada didalamnya. Menurut Ismail (2010), Unsur-unsur yang terkandung dalam pemberian fasilitas kredit adalah sebagai berikut : Kreditur, Debitur, Kepercayaan (trust), Kesepakatan/Perjanjian, Jangka Waktu, Resik, balas jasa.

\section{b. Jenis - Jenis Kredit}

Beragam jenis kegiatan usaha mengakibatkan beragam pula kebutuhan akan jenis kreditnya. Dalam prakteknya, terdapat beberapa jenis kredit yang difasilitasi oleh pihak bank kepada masyarakat. Pemberian fasilitas kredit oleh bank dikelompokkan kedalam jenis kredit yang masing-masing dilihat dari berbagai segi. Pembagian jenis kredit ini ditujukan untuk mencapai sasaran atau tujuan tertentu, mengingat setiap jenis usaha memiliki berbagai karakteristik masing-masing yang berbeda-beda. (Kasmir, 2012) Secara umum jenis-jenis kredit yang diberikan oleh bank dilihat dari berbagai segi adalah sebagai berikut : Dilihat dari segi kegunaan Kredit Investasi, Kredit Modal Kerja. Dilihat dari segi tujuan kredit Kredit produktif, Kredit Konsumtif. Dilihat dari segi jangka waktu : Kredit Jangka Pendek, Kredit Jangka Menengah, Kredit Jangka Panjang. Dilihat dari segi jaminan : Kredit Dengan Jaminan (Secured Loan), Kredit Tanpa Jaminan (Unsecured Loan). Dilihat dari segi sektor usaha : Kredit Pertanian, Kredit Peternakan, Kredit Industri, Kredit Pertambangan, Kredit Pendidikan, Kredit Profesi, Kredit Perumahan, dan kredit sektor usaha lainnya.

\section{Pengertian Non Performing Loan}

Kredit bermasalah atau Non Performing Loan merupakan resiko yang terkandung dalam setiap pemberian fasilitas kredit oleh suatu lembaga perbankan. Tidak ada satupun lembaga bank yang tidak mengalami yang namanya kredit bermasalah atau Non Performing Loan. Menurut Ismail (2010), kredit bermasalah atau Non Performing Loan merupakan kredit yang telah disalurkan oleh bank, dimana debitur tidak dapat melakukan pembayaran angsuran kreditnya sesuai dengan perjanjian yang telah ditandatangani oleh pihak bank dan debitur. Kredit bermasalah atau Non Performing Loan, akan berakibat pada kerugian bank karena tidak diterimanya 


\section{"Vol 3, No 1 (2019): July - Desember"}

kembali dana yang telah disalurkan bank untuk fasilirtas kredit, dan pendapatan bunga yang tidak dapat diterima sebagai balas jasa atas pemberian fasilitas kredit tersebut. Dengan demikian artinya, dana bank kehilangan kesempatan untuk mendapatkan bunga. Hal ini berakibat pada penurunan pendapatan bank secara total. Jika hal tersebut terjadi berkepanjangan akan mempengaruhi dan membahayan kelangsungan hidup suatu lembaga bank.

\section{Penggolongan Non Performing Loan}

Menurut Hermansyah (2011), sesuai ketentuan dalam Pasal 12 Ayat (3) Peraturan Bank Indonesia (PBI) No. 7/2/PBI./2005 tentang Penilaian Kualitas Aktiva Bank Umum, kredit yang dikategorikan sebagai Non Performing Loan adalah apabila kualitas kredit tersebut tergolong pada tingkat kolektibilitas sebagai berikut : Kredit Kurang Lancar (Substandard), Kredit Kurang Lancar (Substandard) merupakan kredit yang telah mengalami tunggakan pembayaran, dimana : (1) Pembayaran pokok pinjaman dan bunga pinjamannya telah mengalami penundaan pembayaran melampaui 90 (sembilan puluh) hari sampai dengan kurang dari 180 (seratus delapan puluh) hari (2) Hubungan debitur dengan pihak bank memburuk (3) Informasi keuangan debitur tidak dapat diyakini oleh bank. Kredit Diragukan (Doubtful), Kredit Diragukan (Doubtful) merupakan kredit yang telah mengalami penundaan pembayaran, dimana : (1) Penundaan pembayaran pokok pinjaman dan bunga pinjamannya antara 180 (seratus delapan puluh) hari sampai dengan 270 (dua ratus tujuh puluh) hari. (2) Hubungan debitur dengan pihak bank semakin memburuk (3) Informasi keuangan debitur sudah tidak dapat dipercaya lagi oleh pihak bank. Kredit Macet (Loss), Kredit Macet (LoSS) merupakan kredit yang mengalami penundaan pembayaran, baik penundaan pembayaran pokok pinjaman maupun pembayaran bunga pinjaman yang telah melampaui 270 (dua ratus tujuh puluh) hari. Pada kondisi ini pihak bank mengalami kerugian atas terjadinya kredit macet tersebut. 


\section{"Vol 3, No 1 (2019): July - Desember"}

\section{Rasio Non Performing Loan}

Rasio Non Performing Loan adalah rasio yang menggambarkan tingkat persentase tertentu antara jumlah kredit bermasalah yaitu jumlah kredit kurang lancar, kredit diragukan dan kredit macet dibandingkan dengan total kredit yang diberikan. Berdasarkan Surat Edaran Bank Indonesia (SEBI) No. 6/23/DPNP, tanggal 31 Mei 2004, tentang Kriteria Penetapan Peringkat Profil Risiko dengan rasio Non Performing Loan, besarnya persentase Non Performing Loan dapat dihitung dengan Formulasi Non Performing Loan (NPL), sebagai berikut :

$$
\underset{N P L=}{\frac{\text { Kredit Kurang Lancar+Kredit Diragukan+Kredit Macet }}{\text { Total Kredit Yang Diberikan }}} \times 100
$$

\begin{tabular}{ll}
\hline Dimana : & \\
\hline NPL & $:$ Rasio Kredit Bermasalah \\
\hline Kredit Kurang Lancar & $:$ Penundaan pembayaran melampaui 90 hari \\
\hline Kredit Diragukan & $:$ Penundaan pembayaran melampaui 180 hari \\
\hline Kredit Macet & $:$ Penundaan pembayaran melampaui 270 hari \\
\hline
\end{tabular}

\section{Faktor Penyebab Non Performing Loan}

Menurut Ismail (2010)terdapat beberapa faktor penyebab terjadinya Non Performing Loan, sebagai berikut : Faktor Intern Bank, meliputi : (1) Tidak diterapkan prinsip-prinsip kehati-hatian dalam analisis dan pemberian kredit. (2). Analisis kredit yang kurang tepat, (3) Adanya kolusi antara pejabat bank yang menangani kredit (4) Adanya campur tangan terlalu besar dari pihak internal bank (5) Kelemahan dalam melakukan pembinaan dan monitoring kredit. Faktor Ekstern Bank, antara lain meliputi : (1) Debitur dengan itikad tidak baik. (2) Adanya penyelewengan kredit yang dilakukan oleh debitur. (3) Unsur ketidaksengajaan debitur. (4) Usaha debitur yang sedang lesu. (5) Debitur kurang mampu mengelola usahanya. (6) Adanya perubahan kebijakan pemerintah dalam sektor riil. (7) Terjadinya bencana alam, kecelakaan kerja, musibah dan lain-lain yang merugikan usaha debitur. 


\section{Dampak Non Performing Loan}

Siswanto Sutojo (2008) mengemukakan bahwa Non Performing Loan dalam jumlah besar akan mendatangkan dampak yang sangat merugikan baik bagi bank sebagai pemberi kredit, industri perbankan pada umumnya, maupun terhadap kehidupan perekonomian nasional. Suatu lembaga bank yang memiliki rating Non Performing Loan dalam jumlah besar akan mengalami hal-hal yang merugikan bank bersangkutan antara lain sebagai berikut : Oleh Bank Indonesia (BI), kredit bermasalah atau Non Performing Loan dikategorikan sebagai aktiva produktif bank yang telah diragukan kualitas kolektibiltasnya. Oleh karena itu untuk menjaga keamanan dana para nasabah sebagai penyedia dana atau sumber Dana Pihak Ketiga (DPK), maka Bank Indonesia mewajibkan kepada semua bank umum untuk menyediakan dana cadangan kerugian untuk penghapusan kredit bermasalah, yang disebut Penyisihan Penghapusan Aktiva Produktif (PPAP). PPAP tersebut dibentuk untuk menutup kerugian yang ditimbulkan dari penanaman dana bank kedalam suatu kredit.Semakin banyak kredit bermasalah atau Non Performing Loan yang dimiliki oleh suatu bank mewajibkan bank bersangkutan untuk menyediakan dana cadangan kerugian untuk penghapusan kredit bermasalah atau Non Performing Loan yang dimilikinya. Akibatnya penyediaan dana untuk dana cadangan kerugian tersebut akan menguras laba yang dimiliki oleh bank bersangkutan. (2) Menurunnya pendapatan keuntungan bank dari penyaluran kreditnya karena tidak diterimanya kembali hasil pemberian kredit oleh bank yaitu pendapatan yang diperoleh dari bunga kredit yang dibebankan kepada debitur, Return of Assets (ROA) sebagai salah satu tolok ukur profitabilitas bagi bank akan menurun karena kecenderungan bank menurunkan labanya karena menutupi kerugian dari kredit bermasalah atau Non Performing Loan. Akibatn, penilaian dari tingkat kesehatan dan likuidnya bank tersebut dimasyarakat dan juga di industri perbankan akan menurun. (3) Kerugian lainnya yang akan ditanggung oleh bank karena kredit bermasalah atau Non Performing Loan ini adalah harus mengurangi modal kerja bank, dimana hal tersebut akan menurunkan jumlah persentase kekuatan modal bank (Capital Adequacy Ratio - CAR). Untuk menstabilkan persentase CAR tersebut, maka bank bersangkutan 


\section{"Vol 3, No 1 (2019): July - Desember"}

harus berusaha mencari dan memasukkan lagi dana modal segar. Apabila bank tidak dapat memasukkan dana modal segar tersebut maka nilai likuid operasi bank akan menurun. (Siswanto Sutojo, 2008). Secara garis besar dampak kredit bermasalah atau Non Performing Loan dalam jumlah besar terhadap bank umum mengakibatkan menurunnya tingkat operasi bank bersangkutan. Penurunan mutu kredit yang parah dan terus berlanjut akan mempengaruhi likuiditas dan solvabilitas suatu bank, serta mengancam kelangsungan hidup bank bersangkutan. Keadaan bank yang demikian akan mempengaruhi kepercayaan para nasabah maunpun calon nasabah serta stakeholder yang berkepentingan dengan bank tersebut.

\section{Upaya Penanganan Non Performing Loan (NPL)}

Dalam prakteknya meskipun bank telah melakukan analisis yang cermat, resiko Non Performing Loan tetap saja sering terjadi disuatu bank. Semua bank pada dasarnya memiliki kredit bermasalah, karena pada prakteknya tidak semua kredit yang disalurkan bank akan berjalan lancar. (Siswanto. S, 2008) Menurut Ismail (2010), upaya yang dilakukan bank untuk penyelamatan terhadap kredit bermasalah (Non Performing Loan) antara lain : (1) Rescheduling (Penjadwalan kembali), (2) Reconditioning (Persyaratan kembali), Reconditioning merupakan upaya yang dilakukan bank dalam menyelamatkan kredit bermasalah atau Non Performing Loan dengan mengubah seluruh atau sebagian perjanjian kredit yang telah dilakukan bank dengan debitur. Perubahan kondisi dan persyaratan tersebut harus disesuaikan dengan permasalahan yang dihadapi debitur dalam menjalankan usahanya. (3) Restructuring (Penataan kembali), (4) Restructuring merupakan upaya yang dilakukan oleh bank dalam menyelamatkan kredit bermasalah dengan cara mengubah struktur pembiayaan yang mendasari pemberian kredit. (5) Kombinasi, Upaya penyelamatan kredit dengan cara kombinasi sebagai berikut :1) Rescheduling dan Restructuring Upaya gabungan antara Rescheduling dan Restructuring dilakukan misalnya, bank memperpanjang jangka waktu kredit dan menambah jumlah kredit. 2) Rescheduling dan Reconditioning Upaya gabungan antara Rescheduling dan Reconditioning dilakukan dengan memperpanjang jangka 


\section{"Vol 3, No 1 (2019): July - Desember"}

waktu kredit dan meringankan bunga. 3) Restructuring dan Reconditioning Upaya penambahan kredit diikuti dengan keringanan bunga atau pembebasan tunggakan bunga yang membantu memperkecil angsuran. 4) Rescheduling, Restructuring dan Reconditioning. 5) Upaya gabungan dari ketiga cara tersebut merupakan upaya maksimal yang dilakukan oleh bank, misalnya jangka waktu kredit diperpanjang, kredit ditambah dan tunggakan bunga dibebaskan. (6) Eksekusi, Eksekusi merupakan alternatif terakhir yang dapat dilakukan oleh bank untuk menyelamatkan kredit bermasalah. Eksekusi merupakan penjualan agunan yang dimiliki oleh bank. Hasil penjualan agunan diperlukan untuk melunasi semua kewajiban debitur, baik kewajiban atas pinjaman pokok, dan kewajiban atas bunga pinjaman. Sisa dari penjualan agunan yang dilakukan oleh bank setelah melunasi semua kewajiban debitur pada bank akan dikembalikan kepada debitur. Sebaliknya kekurangan atas hasil dari penjualan agunan menjadi tanggungan debitur, artinya debitur diwajibkan untuk membayar kekurangannya. Pada prakteknya, bank tidak dapat lagi menagih kepada debitur untuk melunasi hutangnya. Atas kerugian karena hasil penjualan agunan tidak cukup untuk melunasi semua hutang debitur, maka bank akan membebankan kerugian tersebut menjadi kerugian bank.

\section{METODE PENELITIAN}

Metode yang digunakan dalam penelitian ini adalah metode penelitian deskriptif, Metode pengumpulan data dalam penelitian ini adalah : (1) Observasi ke lokasi penelitian, yaitu pada PT. Bank Tabungan Pensiunan Nasional, Tbk Mitra Usaha Rakyat Kantor Cabang Pembantu Tolitoli, di JIn.Usman Binol Kelurahan Baru Kecamatan Baolan Kabupaten Tolitoli. (2) Wawancara secara langsung dengan pihak - pihak yang bertanggung jawab dalam perusahaan, seperti pimpinan perusahaan dan karyawan bagian kredit pada PT. Bank Tabungan Pensiunan Nasional, Tbk Mitra Usaha Rakyat Kantor Cabang Pembantu Tolitoli (3) Studi pustaka, yaitu dengan mempelajari literatur buku-buku terkait objek penelitian,

referensi terkait materi tentang objek penelitian dari media sosial, dan Laporan 


\section{"Vol 3, No 1 (2019): July - Desember"}

Performance Tahunan Cabang PT. Bank Tabungan Pensiunan Nasional, Tbk Mitra Usaha Rakyat Kantor Cabang Pembantu Tolitoli.

\section{HASIL PENELITIAN DAN PEMBAHASAN}

\section{Penyaluran Kredit PT. Bank Tabungan Pensiunan Nasional, Tbk Mitra Usaha Rakyat Kantor Cabang Pembantu Tolitoli}

Dalam usaha mencapai keuntungan yang maksimal melalui paya pencapaian penyaluran kredit yang optimal sebagai aktivitas suatu lembaga bank, maka sangat diperlukan manajemen kredit yang tepat dan efektif dilakukan dalam operasional bank. Manajemen kredit yang tepat dan efektif akan membantu pencapaian penyaluran kredit yang optimal dengan tetap terjaga kualitas kredit yang sehat seiring dengan peningkatan kredit tersebut. Laporan Performance Tahunan dari PT. Bank Tabungan Pensiunan Nasional, Tbk Mitra Usaha Rakyat Kantor Cabang Pembantu Tolitoli tahun 2011 sampai dengan tahun 2016, menunjukkan aktivitas penyaluran kredit bank bersangkutan, yang tampak dalam tabel sebagai berikut :

Tabel 1

Penyaluran Kredit

PT. Bank Tabungan Pensiunan Nasional, Tbk Mitra Usaha Rakyat Kantor Cabang Pembantu Tolitoli Tahun 2011 - 2016

\begin{tabular}{c|c}
\hline Tahun & $\begin{array}{c}\text { Penyaluran Kredit } \\
\text { (Rp) }\end{array}$ \\
\hline 2011 & $12.343 .000 .000,-$ \\
\hline 2012 & $16.094 .000 .000,-$ \\
\hline 2013 & $19.719 .000 .000,-$ \\
\hline 2014 & $21.920 .000 .000,-$ \\
\hline 2015 & $21.563 .000 .000,-$ \\
\hline 2016 & $16.416 .000 .000,-$ \\
\hline
\end{tabular}




\section{Sumber : PT. Bank Tabungan Pensiunan Nasional, Tbk Mitra Usaha Rakyat Kantor Cabang Pembantu Tolitoli (Data Diolah)}

\section{Tingkat Kolektibilitas Kredit PT. Bank Tabungan Pensiunan Nasional, Tbk Mitra Usaha Rakyat Kantor Cabang Pembantu Tolitoli}

Tingkat Kolektibilitas kredit sesuai kebijakan internal yang berlaku pada PT. Bank Tabungan Pensiunan Nasional, Tbk Mitra Usaha Rakyat Kantor Cabang Pembantu Tolitoli yang ditetapkan berdasarkan kemampuan membayar nasabah adalah sebagai berikut : (1) Kolektibiltas Lancar (Kol 1), yaitu suatu kredit dimana pembayaran kreditnya tepat waktu dengan memenuhi semua persyaratan. (2) Kolektibilitas Special Mention (Dalam Perhatian Khusus) atau Kol 2 terbagi atas 3 waktu jatuh tempo, sebagai berikut : 1) Kolektibilitas 2a, yaitu kredit dengan tunggakan pembayaran kredit mulai dari 1 (satu) hari sampai dengan 30 (tiga puluh) hari. 2) Kolektibiltas 2b, yaitu kredit dengan tunggakan pembayaran kredit mulai dari 31 (tiga puluh satu) hari sampai dengan 60 (enam puluh) hari. 3) Kolektibilitas 2c, yaitu kredit dengan tunggakan pembayaran kredit mulai dari 61 (enam puluh satu) sampai dengan 90 (sembilan puluh) hari. (3) Kolektibilitas Kurang Lancar (Kol 3), yaitu kredit dengan tunggakan pembayaran kredit mulai dari 91 (sembilan puluh satu) hari sampai dengan 120 (seratus dua puluh) hari. (4) Kolektibilitas Diragukan (Kol 4), yaitu kredit dengan tunggakan pembayaran kredit mulai 121(seratus dua puluh satu) hari sampai dengan 180 (seratus delapan puluh) hari. (5) Kolektibilitas Macet (Kol 5), yaitu kredit dengan tunggakan pembayaran lebih dari 180 (seratus delapan puluh) hari.

Rasio Non Performing Loan PT. Bank Tabungan Pensiunan Nasional, Tbk Mitra Usaha Rakyat Kantor Cabang Pembantu Tolitoli

Jumlah Non Performing Loan dari masing-masing kolektibilitas kredit pada PT. Bank Tabungan Pensiunan Nasional, Tbk Mitra Usaha Rakyat Kantor Cabang Pembantu Tolitoli, dapat dilihat pada tabel berikut ini :

Tabel 2.

Non Performing Loan 
"Vol 3, No 1 (2019): July - Desember"

PT. Bank Tabungan Pensiunan Nasional, Tbk Mitra Usaha Rakyat Kantor Cabang Pembantu Tolitoli Tahun 2011

\begin{tabular}{|c|c|c|c|}
\hline No & Kolektibilitas Kredit & $\begin{array}{l}\text { Non Performing Loan } \\
\text { (Rp) }\end{array}$ & Jumlah Kredit (Rp) \\
\hline 1 & Lancar & - & 11.701.164.000,- \\
\hline 2 & $\begin{array}{l}\text { Dalam Perhatian } \\
\text { Khusus }\end{array}$ & - & 469.034.000,- \\
\hline 3 & Kurang Lancar & 111.087.000,- & - \\
\hline 4 & Diragukan & 24.686..000,- & - \\
\hline 5 & Macet & 37.029.000,- & - \\
\hline & Total NPL (Rp) & 172.802.000,- & \\
\hline
\end{tabular}

\section{Sumber : PT.Bank Tabungan Pensiunan Nasional, Tbk Mitra Usaha Rakyat Kantor Cabang Pembantu Tolitoli (Data Diolah)}

Rasio Non Performing Loan tahun 2011 :

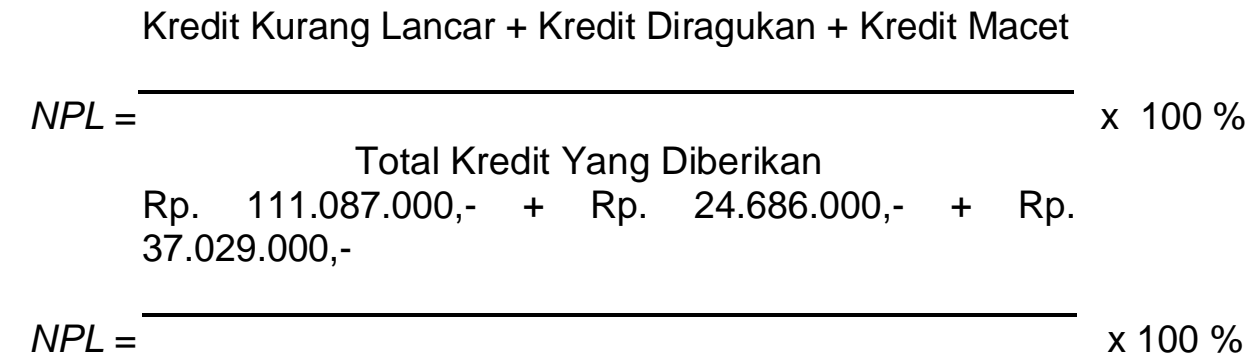

Rp. 12.343.000.000,-

Rp. 172.802.000,-

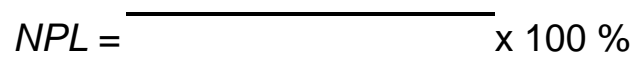

$$
N P L=1,4{ }^{\text {Rp.12.343.000.000,- }}
$$

Non Performing Loan $=1,4 \%$ menunjukkan bahwa dari total kredit yang diberikan PT. Bank Tabungan Pensiunan Nasional, Tbk Mitra Usaha Rakyat Kantor Cabang 
“Vol 3, No 1 (2019): July - Desember”

Pembantu Tolitoli ditahun 2011 sebesar 1,4 \% dari kredit tersebut adalah Non Performing Loan yaitu kredit yang mengalami tunggakan pembayaran lebih dari 90 hari sampai lebih dari 180 hari.

Tabel 3

Non Performing Loan

PT. Bank Tabungan Pensiunan Nasional, Tbk Mitra Usaha Rakyat Kantor

Cabang Pembantu Tolitoli Tahun 2012

Kolektibilitas Kredit Non Performing Loan Jumlah Kredit (Rp) (Rp)

\begin{tabular}{llll}
\hline $\mathbf{1}$ & Lancar & - & $15.063 .984 .000,-$ \\
\hline $\mathbf{2}$ & $\begin{array}{l}\text { Dalam } \\
\text { Khusus }\end{array}$ & $515.008 .000,-$ \\
\hline $\mathbf{3}$ & Kurang Lancar & $96.564 .000,-$ & - \\
\hline $\mathbf{4}$ & Diragukan & $354.068 .000,-$ & - \\
\hline & & & - \\
\hline $\mathbf{5}$ & Maceit & $64.376 .000,-$ & \\
\hline & $\cdot$ & & \\
\hline
\end{tabular}

Total Kredit / Outstanding Loans (Rp)

16.094.000.000,-

Sumber: PT.Bank Tabungan Pensiunan Nasional,

Tbk Mitra Usaha Rakyat Kantor Cabang

Pembantu Tolitoli (Data Diolah)

Rasio Non Performing Loan tahun 2012 :

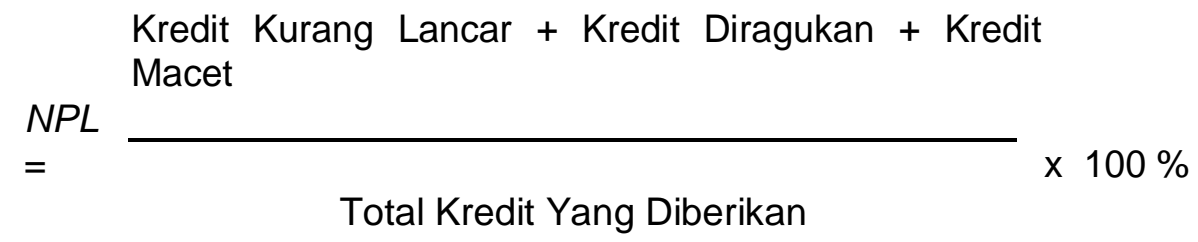

Rp. 96.564.000,- + Rp. 354.068.000,- + Rp. 64.376.000,-

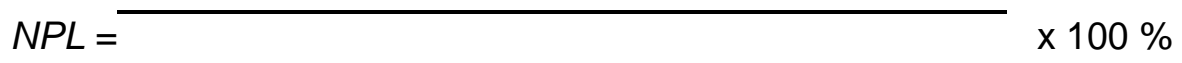

Rp. 16.094.000.000,-

Rp. 515.008.000,-

$N P L=\bar{x} \times 100 \%$ 


\section{"Vol 3, No 1 (2019): July - Desember"}

Rp. 16.094.000.000,-

$N P L=3,2 \%$

Non Performing Loan $=3,2 \%$ menunjukkan bahwa dari total kredit yang diberikan PT. Bank Tabungan Pensiunan Nasional, Tbk Mitra Usaha Rakyat Kantor Cabang Pembantu Tolitoli ditahun 2012 sebesar 3,2 \% dari kredit tersebut adalah Non Performing Loan yaitu kredit yang mengalami tunggakan pembayaran lebih dari 90 hari sampai lebih dari 180 hari.

Tabel 4.

Non Performing Loan

PT. Bank Tabungan Pensiunan Nasional, Tbk Mitra Usaha Rakyat Kantor Cabang Pembantu Tolitoli Tahun 2013

Kolektibilitas Kredit Non Performing Loan Jumlah Kredit

(Rp)

(Rp)

\begin{tabular}{llll}
\hline $\mathbf{1}$ & Lancar & - & $18.378 .108 .000,-$ \\
\hline $\mathbf{2}$ & $\begin{array}{l}\text { Dalam Perhatian } \\
\text { Khusus }\end{array}$ & - & $1.123 .983 .000,-$ \\
& & & - \\
\hline $\mathbf{3}$ & Kurang Lancar & $59.157 .000,-$ & - \\
\hline $\mathbf{4}$ & Diragukan & $157.75 .2 .000,-$ & - \\
\hline $\mathbf{5}$ & Macet & $0,-$ & \\
\hline & Total NPL (Rp) & $\mathbf{2 1 6 . 9 0 9 . 0 0 0 , -}$ & \\
\hline
\end{tabular}

Total Kredit / Outstanding Loans (Rp) 19.719.000.000,-

Sumber: PT.Bank Tabungan Pensiunan Nasional,

Tbk Mitra Usaha Rakyat Kantor Cabang

Pembantu Tolitoli (Data Diolah)

Rasio Non Performing Loan tahun 2013 :

$$
\begin{aligned}
& \text { Kredit Kurang Lancar + Kredit Diragukan + Kredit Macet }
\end{aligned}
$$

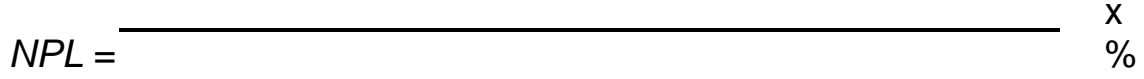




$$
N P L=\frac{\text { Rp. } 59.157 .000,-+ \text { Rp. } 157.752 .000,-+ \text { Rp. 0,- }}{\text { Rp. } 19.719 . .000 .000,-} \times 100 \%
$$

Rp. 216.909.000,-

$$
N P L=\bar{x} \times 100 \%
$$

\begin{tabular}{|c|c|c|c|}
\hline & Kolektibilitas Kredit & $\begin{array}{l}\text { Non Performing Loan } \\
\text { (Rp) }\end{array}$ & $\begin{array}{l}\text { Jumlah Kredit } \\
\text { (Rp) }\end{array}$ \\
\hline 1 & Lancar & - & 20.539.040.000,- \\
\hline 2 & $\begin{array}{l}\text { Dalam Perhatian } \\
\text { Khusus }\end{array}$ & - & 920.640.000,- \\
\hline 3 & Kurang Lancar & 372.640.000,- & - \\
\hline 4 & Diragukan & $65.760 .000,-$ & - \\
\hline \multirow[t]{3}{*}{5} & Macet & 21.920.000,- & - \\
\hline & Total NPL (Rp) & 460.320.000,- & \\
\hline & \multicolumn{2}{|c|}{ Total Kredit / Outstanding Loans (Rp) } & 21.920.000.000,- \\
\hline
\end{tabular}

Rp. 19.719..000.000,-

$N P L=1,1 \%$ 


\section{"Vol 3, No 1 (2019): July - Desember"}

Non Performing Loan $=1,1 \%$ menunjukkan bahwa dari total kredit yang diberikan PT. Bank Tabungan Pensiunan Nasional, Tbk Mitra Usaha Rakyat Kantor Cabang Pembantu Tolitoli ditahun 2013 sebesar 1,1 \% dari kredit tersebut adalah Non Performing Loan yaitu kredit yang mengalami tunggakan pembayaran lebih dari 90 hari sampai dengan 180 hari.

\section{Tabel 5 \\ Non Performing Loan \\ PT. Bank Tabungan Pensiunan Nasional, Tbk Mitra Usaha Rakyat Kantor Cabang Pembantu Tolitoli Tahun 2014}

\section{Rasio Non Performing Loan tahun 2014 :}

$$
\begin{gathered}
N P L=\frac{\text { Kredit Kurang Lancar }+ \text { Kredit Diragukan }+ \text { Kredit Macet }}{\text { Total Kredit Yang Diberikan }} \times 100 \% \\
N P L=\frac{\text { Rp. } 372.640 .000,-+ \text { Rp. } 65.760 .000,-+ \text { Rp. } 21.920 .000,-}{} \times 100 \%
\end{gathered}
$$$$
\text { Rp. 21.920.000.000,- }
$$

Rp. 460.320.000,-

$$
\begin{aligned}
& N P L=\longdiv { x } 1 0 0 \% \\
& \text { Rp. 21.920.000.000,- } \\
& N P L=2,1 \% \\
& \text { Sumber : PT.Bank Tabungan Pensiunan } \\
& \text { Nasional,Tbk Mitra Usaha Rakyat Kantor } \\
& \text { Cabang Pembantu Tolitoli(Data Diolah) }
\end{aligned}
$$

Non Performing Loan = 2,1 \% menunjukkan bahwa dari total kredit yang diberikan PT. Bank Tabungan Pensiunan Nasional, Tbk Mitra Usaha Rakyat Kantor Cabang Pembantu Tolitoli ditahun 2014 sebesar 2,1 \% dari kredit tersebut adalah Non 
“Vol 3, No 1 (2019): July - Desember”

Performing Loan yaitu kredit yang mengalami tunggakan pembayaran lebih dari 90 hari sampai lebih dari 180 hari.

Non Performing Loan

PT. Bank Tabungan Pensiunan Nasional, Tbk Mitra Usaha Rakyat Kantor Cabang Pembantu Tolitoli Tahun 2015

Kolektibilitas Kredit Non Performing Loan Jumlah Kredit (Rp)

(Rp)

\begin{tabular}{|c|c|c|c|}
\hline 1 & Lancar & - & 19.320.448.000,- \\
\hline 2 & $\begin{array}{l}\text { Dalam Perhatian } \\
\text { Khusus }\end{array}$ & - & 1.617.225.000,- \\
\hline \multirow[t]{2}{*}{3} & Kurang Lancar & 172.504.000,- & - \\
\hline & . & . & \\
\hline 4 & Diragukan & 366.571.000,- & - \\
\hline \multirow[t]{3}{*}{5} & Macet & $86.252 .000,-$ & - \\
\hline & Total NPL (Rp) & 625.327.000,- & \\
\hline & $\begin{array}{l}\text { Total Kredit } \\
\text { (Rp) }\end{array}$ & / Outstanding Loans & 21.563.000.000,- \\
\hline
\end{tabular}

Sumber : PT.Bank Tabungan Pensiunan Nasional,Tbk Mitra Usaha Rakyat Kantor Cabang Pembantu Tolitoli (Data Diolah)

Rasio Non Performing Loan tahun 2015 :

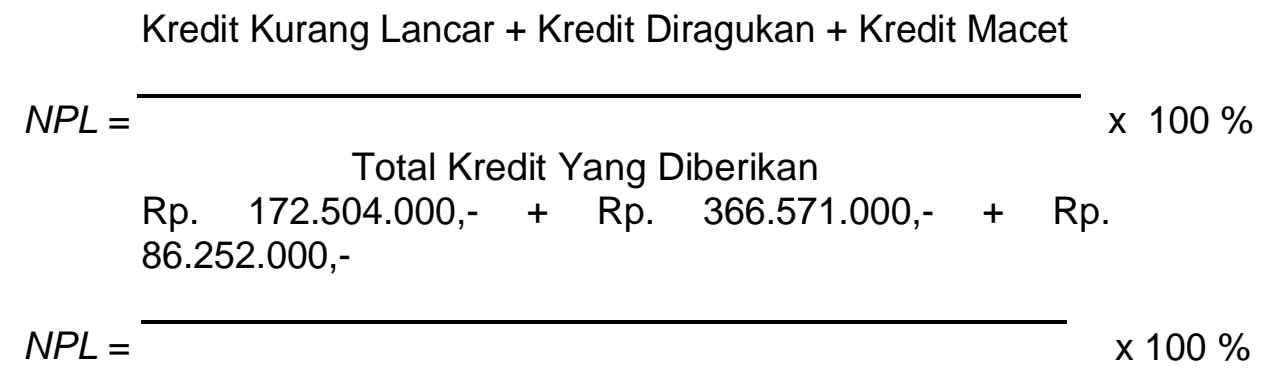

Rp. 21.563.000.000,- 


$$
N P L=2,9 \%
$$

Non Performing Loan $=2,9 \%$ menunjukkan bahwa dari total kredit yang diberikan PT. Bank Tabungan Pensiunan Nasional, Tbk Mitra Usaha Rakyat Kantor Cabang Pembantu Tolitoli ditahun 2015 sebesar 2,9 \% dari kredit tersebut adalah Non Performing Loan yaitu kredit yang mengalami tunggakan pembayaran lebih dari 90 hari sampai lebih dari 180 hari.

\section{Tabel 7.}

Non Performing Loan

PT. Bank Tabungan Pensiunan Nasional, Tbk Mitra Usaha Rakyat Kantor Cabang Pembantu Tolitoli Tahun 2016

\begin{tabular}{|c|c|c|c|}
\hline & Kolektibilitas Kredit & $\begin{array}{l}\text { Non Performing Loan } \\
\text { (Rp) }\end{array}$ & $\begin{array}{l}\text { Jumlah Kredit } \\
\text { (Rp) }\end{array}$ \\
\hline 1 & Lancar & - & 15.250.464.000,- \\
\hline 2 & $\begin{array}{l}\text { Dalam Perhatian } \\
\text { Khusus }\end{array}$ & - & 1.132.704.000,- \\
\hline 3 & Kurang Lancar & $0,-$ & - \\
\hline 4 & Diragukan & 32.832.000,- & - \\
\hline 5 & Macet & $0,-$ & - \\
\hline & Total NPL (Rp) & 32.832.000,-- & \\
\hline
\end{tabular}

- Total Kredit / Outstanding Loans (Rp) 16.416.000.000,-

Sumber: PT.Bank Tabungan Pensiunan Nasional,

Tbk Mitra Usaha Rakyat Kantor Cabang

Pembantu Tolitoli (Data Diolah)

Rasio Non Performing Loan tahun 2016 :

$$
N P L=\frac{\text { Kredit Kurang Lancar }+ \text { Kredit Diragukan }+ \text { Kredit Macet }}{\text { Total Kredit Yang Diberikan }} \times 100 \%
$$$$
\text { Rp. 0,- + Rp. 32.832.000,- + Rp. 0,- }
$$ 
“Vol 3, No 1 (2019): July - Desember”

$$
N P L=\overline{100 \%}
$$

Rp. 16.416.000.000,-

$$
\begin{aligned}
& \text { Rp. 32.832.000,- } \\
& N P L=\bar{x} 100 \%
\end{aligned}
$$

Rp. 16.416.000.000,-

\begin{abstract}
$N P L=0,2 \%$
Non Performing Loan $=0,2 \%$ menunjukkan bahwa dari total kredit yang diberikan PT. Bank Tabungan Pensiunan Nasional, Tbk Mitra Usaha Rakyat Kantor Cabang Pembantu Tolitoli ditahun 2016 sebesar 0,2 \% dari kredit tersebut adalah Non Performing Loan yaitu kredit yang mengalami tunggakan pembayaran lebih dari 90 hari sampai dengan 180 hari.

\section{Pengelolaan Non Performing Loan PT. Bank Tabungan Pensiunan Nasional, Tbk Mitra Usaha Rakyat Kantor Cabang Pembantu Tolitoli}

Surat Edaran Bank Indonesia (SEBI) No.6/23/DPNP tanggal 31 Mei 2004, tentang Kriteria Penetapan Peringkat Profil Risiko, yang menetapkan batas Non Performing Loan (NPL) untuk bank yang termasuk kategori bank sehat yaitu bank dengan persentase Non Performing Loan (NPL) yang kurang dari $(<) 5 \%$. Kriteria Penetapan Peringkat Profil Risiko ini secara tidak langsung mewajibkan semua bank umum yang ada di Indonesia untuk berupaya menjaga margin NPL-nya tetap berada dibawah 5\% agar tetap termasuk dalam kategori bank yang sehat sesuai peraturan perbankan. PT. Bank Tabungan Pensiunan Nasional, Tbk Mitra Usaha Rakyat Kantor Cabang Pembantu Tolitoli selalu berupaya menekan persentase NPLnya sekecil mungkin. Namun,kenyataannya dalam beberapa tahun persentase NPLnya mengalami fluktuasi. Pada beberapa tahun NPL nya mengalami penurunan dan dalam beberapa tahun juga mengalami peningkatan. Berikut tabel fluktuasi NPL PT. Bank Tabungan Pensiunan Nasional, Tbk Mitra Usaha Rakyat Kantor Cabang Pembantu Tolitoli tahun 2011 - 2016. 
"Vol 3, No 1 (2019): July - Desember"

Tabel 8.

Rekapitulasi Non Performing Loan PT. Bank Tabungan Pensiunan Nasional, Tbk Mitra Usaha Rakyat Kantor Cabang Pembantu Tolitoli Tahun 2011 - 2016

\begin{tabular}{|c|c|c|c|c|}
\hline $\begin{array}{l}\text { Tahu } \\
\mathbf{n}\end{array}$ & Jumlah Kredit & $\begin{array}{l}\text { Non } \\
\text { Loan }\end{array}$ & Performing & $\begin{array}{l}\text { Perkembang } \\
\text { an }\end{array}$ \\
\hline & (Rp) & (Rp) & $\%$ & $N P L(\%)$ \\
\hline 2011 & 12.343.000.000,- & $\begin{array}{l}\text { 172.802.000, } \\
-\end{array}$ & $1,4 \%$ & - \\
\hline 2012 & 16.094.000.000,- & $\begin{array}{l}\text { 515.008.000, } \\
-\end{array}$ & $3,2 \%$ & $1,8 \%$ \\
\hline 2013 & 19.719.000.000,- & 216.909:000, & $1,1 \%$ & $-2,1 \%$ \\
\hline 2014 & 21.920.000.000,- & $\begin{array}{l}460.320 .000 \\
-\end{array}$ & $2,1 \%$ & $1,0 \%$ \\
\hline 2015 & 21.563.0.00.000,- & $\begin{array}{l}\text { 625.327.000, } \\
-\end{array}$ & $2,9 \%$ & $0,8 \%$ \\
\hline 2016 & 16.416.000.000,- & $32.832 .000,-$ & $0,2 \%$ & $-2,7 \%$ \\
\hline
\end{tabular}

Diketahui bahwa tahun 2011 persentase NPL sebesar Rp. 172.802.000,-atau 1,4\% dari total kredit yang disalurkan pada tahun tersebut. Pada tahun 2012 terjadi peningkatan persentase NPL sebesar 1,8\% dari NPL tahun 2011 sehingga NPL menjadi 3,2\% atau sebesar Rp. 515.008,-. Peningkatan persentase NPL ini sangat signifikan atau merupakan peningkatan NPL yang tertinggi dibandingkan tahuntahun lainnya. Kemudian ditahun 2014 terjadi lagi peningkatan persentase NPL sebesar 1,0\% dari NPL tahun 2013 sehingga NPL menjadi 2,1\% atau sebesar Rp. 515.008,-,. Ditahun 2015 terjadi lagi peningkatan persentase NPL sebesar 0,8\% dari NPL tahun 2014 sehingga NPL menjadi 2,9\% atau sebesar Rp. 625.327.000. Peningkatan persentase NPL yang terjadi pada beberapa tahun yaitu tahun 2012, 


\section{"Vol 3, No 1 (2019): July - Desember"}

tahun 2014 dan tahun 2015, secara garis besar disebabkan oleh faktor-faktor antara lain sebagai berikut ini :

1) Debitur melakukan pengembangan atau ekspansi usaha yang terlalu besar, yang membutuhkan modal kerja yang besar juga. Tidak terpenuhinya modal kerja untuk ekspansi usaha tersebut mengakibatkan menurunnya produksi. Penurunan aktivitas produksi menyebabkan berkurangnya pendapatan dan keuntungan usaha debitur. Hal ini mempengaruhi kapasitas debitur untuk membayar kreditnya

2) Menurunnya kapasitas produksi perusahaan manufaktur yang disebabkan oleh kurang tersedianya bahan baku yang dibutuhkan karena bahan baku tersebut harus dibeli diluar daerah. Menurunnya kapasitas produksi ini menyebabkan berkurangnya pendapatan yang berdampak pada pembayaran kredit

3) Menurunnya volume penjualan perusahaan dagang, yang disebabkan oleh kurangnya persediaan barang dagang yang ada karena masalah keterlambatan pengiriman barang karena dibeli dari luar kota, berkaitan dengan masalah izin pengiriman, proses pengiriman dan biaya pengiriman yang besar. Contoh usaha penjualan barang elektronik. Akibat penurunan volume penjualan ini mengakibatkan kurangnya pendapatan perusahaan. Tentu saja sangat mempengaruhi kemampuan membayar kreditnya.

4) Terjadi penyelewengan kredit oleh debitur, yakni penggunaan kredit yang melenceng dari tujuan pemberian kredit, sehingga kredit tidak efektif. Contohnya kredit untuk menambah modal kerja digunakan untuk membangun gedung atau membeli kendaraan. Ada juga kredit untuk investasi yaitu untuk membeli kendaraan operasional tetapi malah digunakan debitur untuk membeli 


\section{"Vol 3, No 1 (2019): July - Desember"}

kendaraan pribadi dengan alasan untuk keperluan operasional usaha. Penyalahgunaan kredit ini mengakibatkan kredit menjadi tidak efektif

5) Debitur yang kurang mampu mengelola usaha barunya, dan hanya mengandalkan tenaga kerja. Hal ini terjadi pada debitur yang sebelumnya sudah punya usaha kemudian bermohon kredit untuk membuka usaha yang baru dengan motif spekulatif, tanpa mengkaji lebih jauh prospek usaha yang akan digeluti. Kredit yang diterimapun digunakan untuk memodali usaha barunya. Misalnya debitur yang pengalaman dan dunia usahanya adalah dibidang pertanian, kemudian merintis usaha baru seperti penjualan dan servis alat-alat elektronik, tetapi tidak dikerjakan sendiri oleh debitur melainkan hanya mengandalkan tenaga kerja atau pegawai. tenaga kerja yang bekerja maka usahapun langsung macet. Apalagi untuk jenis usaha servis yang memerlukan tenaga kerja yang terdidik dan terlatih.

6) Terjadinya kecelakaan transportasi atau pengiriman yang menghambat aktivitas produksi dan penjualan perusahaan. Contohnya perusahaan manufaktur seperti meubel yang bahan bakunya berasal dari luar kota, pada saat pengiriman lewat transportasi laut mengalami kecelakaan dan mengakibatkan kayu yang diangkut tenggelam dan hilang. Ada juga jenis usaha dagang yang mengalami kerugian karena kecelakaan pesawat, sementara pada pesawat tersebut diangkut barang-barang elektronik yang akan diperdagangkan. Kecelakaan tersebut menyebabkan perusahaan tidak bisa berproduksi dan juga mengalami kerugian. Hal tersebut akan mempengaruhi kapasitas perusahaan dalam membayar kreditnya Terjadi goncangan stabilitas ekonomi daerah, seperti terjadinya kenaikan harga-harga, diawali dengan kenaikan harga bahan bakar minyak, 


\section{"Vol 3, No 1 (2019): July - Desember"}

kemudian disusul dengan kenaikan harga barang kebutuhan pokok. Kenaikan ini memicu terjadinya kenaikan harga bahan baku dan biaya transportasi. Ditambah lagi untuk skala perusahaan adanya tuntutan karyawan akan kenaikan upah/gaji, serta biaya-biaya operasional perusahaan lainnya yang harus dibiayai untuk menunjang proses produksi dan penjualan. Apalagi ketika keadaan ini dihadapkan dengan masalah kurangnya daya beli masyarakat karena ekonomi yang sulit dan lambatnya perputaran uang, sehingga masyarakat mengurangi konsumsi barang, khususnya pakaian dan alat elektronik, sehingga mengurangi volume penjualan perusahaan yang bergerak dibidang manufaktur dan dagang. Volume penjualan menurun sementara kebutuhan biaya operasional perusahaan tetap bahkan ikut meningkat karena adanya kenaikan harga secara umum, seperti kenaikan tarif rekening listrik, telfon dan air, ditambah lagi dengan pajak penghasilan perusahaan. Keadaan ini sudah tentu akan sangat menguras modal kerja perusahaan. Terkurasnya modal kerja tanpa disertai dengan peningkatan pendapatan karena penurunan volume penjualan ini sangat merugikan perusahaan. Akibatnya pada kapasitas perusahaan yaitu perusahaan kesulitan membayar kreditnya

7) Debitur mengalami kecelakaan atau mengalami sakit penyakit dalam kurun waktu yang relatif lama, sehingga debitur tidak dapat menjalankan usahanya, khususnya debitur yang usahanya dikelola sendiri tanpa tenaga kerja, misalnya debitur dengan usaha dagang / pertokoan. Malah modal usaha yang ada justru terpaksa dipakai untuk kebutuhan hidup atau biaya pengobatan dan lainnya. Akibatnya debitur tidak memperoleh pendapatan untuk membiayai hidupnya bahkan tidak mampu membayar kreditnya 


\section{"Vol 3, No 1 (2019): July - Desember"}

8) Terjadi penurunan usaha debitur karena masalah keluarga seperti perceraian. Hal ini dikarenakan usaha yang dibiayai oleh kredit tersebut sejak awal bukan ditangani dan dikelola langsung oleh debitur tetapi oleh pasangan debitur, baik suami atau isteri. Akibatnya ketika terjadi perceraian, maka usahapun tidak lagi dapat dikelola dengan maksimal oleh debitur. Penurunan usaha ini mempengaruhi pendapatan dan keuntungan debitur, sehingga menyebabkan debitur kesulitan memenuhi kewajibannya untuk membayar kreditnya Menangani Non Performing Loan yang menunjukkan peningkatan persentase ditahun 2012, 2014 dan 2015 tersebut PT. Bank Tabungan Pensiunan Nasional, Tbk Mitra Usaha Rakyat Kantor Cabang Pembantu Tolitoli, berupaya untuk melakukan berbagai cara menekan peningkatan persentase NPL setiap tahunnya sekaligus mencegah peningkatan yang sama terjadi ditahun berikutnya. Cara-cara yang dilakukan yaitu melakukan penagihan (collection) kerumah atau ketempat usaha debitur (door to door) secara rutin/berkala. Memastikan setoran angsuran dapat diterima tepat waktu tanpa keterlambatan dengan menjemput setoran angsuran langsung ketempat usaha atau kerumah debitur. Selain itu PT. Bank Tabungan Pensiunan Nasional, Tbk Mitra Usaha Rakyat Kantor Cabang Pembantu Tolitoli juga menawarkan restrukturisasi kredit kepada beberapa debitur klasifikasi kredit menengah untuk memperbaiki struktur kreditnya. Bahkan sejak tahun 2012 PT. Bank Tabungan Pensiunan Nasional, Tbk Mitra Usaha Rakyat Kantor Cabang Pembantu Tolitoli telah menggalakkan dan menjalankan secara rutin sebulan sekali suatu terobosan bank bersangkutan yaitu program pendidikan dan pelatihan usaha gratis kepada debiturnya. Program pelatihan itu dinamakan Capacity To Growth (C2G). Dalam pelaksanaannya program ini memberikan pendidikan dan pelatihan 


\section{"Vol 3, No 1 (2019): July - Desember"}

kepada para debitur mengenai kiat-kiat pengelolaan usaha yang optimal, serta cara memanajemen keuangan secara efisien. Kegiatan tersebut dilakukan dengan tujuan untuk membantu debitur menjadi pelaku usaha yang cerdas dan terampil mengelola usahanya, sehingga usaha mengalami kemajuan dan perkembangan. Perkembangan usaha yang terjadi kontinyu akan meningkatkan penghasilan dan keuntungan debitur. Dengan keadaan usaha yang terus berkembang dan kehidupan finansial yang tetap terjaga kesehatannya, maka debitur tidak akan kesulitan keuangan, sehingga mampu memenuhi semua kebutuhan dan kewajibannya termasuk kewajiban membayar kreditnya kebank. Upaya penanganan Non Performing Loan secara optimal yang dilakukan PT. Bank Tabungan Pensiunan Nasional, Tbk Mitra Usaha Rakyat Kantor Cabang Pembantu Tolitoli dalam beberapa tahun membawa hasil. Hal tersebut dibuktikan dengan menurunnya persentase NPL ditahun 2013 sebesar 2,1\% dari NPL tahun 2012, sehingga NPL menjadi 1,1\% atau sebesar Rp. 216.909.000,-. Memasuki tahun 2016 PT. Bank Tabungan Pensiunan Nasional, Tbk Mitra Usaha Rakyat Kantor Cabang Pembantu Tolitoli kemudian semakin optimal menekan NPLnya supaya tidak mengalami kenaikan ditahun 2016, dengan melakukan berbagai upaya seperti yang sebelumnya telah dilakukan oleh bank bersangkutan, seperti penagihan (collection) secara rutin, restrukturisasi kredit beberapa debitur klasifikasi kredit menengah, serta tetap rutin menjalankan program pendidikan dan pelatihan usaha kepada debitur (C2G). Pelaksanaan program C2G yang dilakukan ditahun 2016 pun lebih spesifik dan efektif, karena pada setiap kesempatan pelaksanaan pelatihan setiap debitur diberikan waktu untuk menyampaikan perkembangan usahanya, termasuk kendala-kendala yang ditemukan dalam pengelolaan usahanya. Lewat program 


\section{"Vol 3, No 1 (2019): July - Desember"}

C2G setiap debitur memperoleh pengetahuan tentang kiat-kiat usaha yang optimal dan cara-cara mengantisipasi kendala dalam usahanya, sehingga usaha kembali lancar dan mendatangkan penghasilan dan keuntungan bagi debitur. Semua upayaupaya ini dilakukan oleh PT. Bank Tabungan Pensiunan Nasional, Tbk Mitra Usaha Rakyat Kantor Cabang Pembantu Tolitoli dengan tujuan untuk menciptakan kredit yang efektif dan berkualitas sehingga dapat meminimalisir risiko NPL. Selain itu, juga untuk membantu menjaga kelangsungan usaha setiap debiturnya. Setelah melakukan berbagai upaya penanganan NPL disepanjang tahun 2016, maka pada akhir tahun 2016 persentase NPL PT. Bank Tabungan Pensiunan Nasional, Tbk Mitra Usaha Rakyat Kantor Cabang Pembantu Tolitoli menunjukkan penurunan yang sangat besar dibandingkan dengan penurunan NPL yang terjadi ditahun 2013. Ditahun 2016 ini terjadi penurunan angka persentase NPL sebesar 2,7\% dari NPL tahun 2015, sehingga NPL menjadi 0,2\% atau sebesar Rp. 32.832.000,-. Penurunan angka persentase NPL yang sangat signifikan ditahun 2016 ini dikarenakan terdapat beberapa debitur khususnya debitur dengan klasifikasi menengah yang melakukan pelunasan kreditnya dibank bersangkutan. Pelunasan kredit oleh beberapa debitur ini selain didukung oleh keuntungan dari usaha yang dibiayai kreditnya oleh bank yang telah mengalami perkembangan, didukung juga dengan pendapatan debitur lainnya seperti penjualan aset lain yang dimiliki oleh debitur yang dipakai untuk melunasi kreditnya dibank. Kecilnya persentase NPL ditahun 2016 didukung juga dengan lebih selektifnya penyaluran kredit ditahun 2016, dengan prinsip kehatihatian yang lebih tinggi, sehingga meminimalisir kredit bermasalah ditahun 2016. Selain itu, bank bersangkutan juga mengupayakan untuk dapat mendeteksi sedini mungkin indikator terjadinya NPL serta bagaimana antisipasi yang harus dilakukan 


\section{"Vol 3, No 1 (2019): July - Desember"}

bank terhadap kemungkinan tersebut, dengan membangun komunikasi dengan debitur secara rutin dengan tujuan agar dapat mengetahui kondisi terkini usaha debitur (customer maintenance). Penanggulangan NPL yang dilakukan bank bersangkutan secara maksimal mulai dari melakukan penagihan (collection) yang lebih rutin kepada debitur, serta menawarkan restrukturisasi kredit kepada debitur merupakan strategi bank untuk menangani kredit bermasalah. Menjalin dan terus menjaga hubungan dan komunikasi yang baik dengan semua debitur serta terus menjalankan program Capacity To Growth (C2G), dilakukan dengan tujuan untuk mencegah resiko Non Performing Loan yang kemungkinan terjadi dengan cara membantu debitur mengembangkan usahanya. Dengan berkembangnya usaha debitur maka debitur tidak akan mengalami masalah kesulitan keuangan, dan debitur akan mampu untuk memenuhi kewajibannya membayar kredit kebank. Perkembangan Non Performing Loan pada PT. Bank Tabungan Pensiunan Nasional, Tbk Mitra Usaha Rakyat Kantor Cabang Pembantu Tolitoli yang terjadi fluktuatif dari tahun 2011 - 2016. Jika dilihat perkembangan NPL berdasarkan perhitungan rasio NPL setiap tahunnya, maka diketahui bahwa pengelolaan Non Performing Loan PT. Bank Tabungan Pensiunan Nasional, Tbk Mitra Usaha Rakyat Kantor Cabang Pembantu Tolitoli telah efektif, dibuktikan dengan persentase NPL yang menunjukkan angka persentase kurang dari (<) 5\% sejak tahun 2011 sampai dengan tahun 2016, sesuai dengan Kriteria Penetapan Peringkat Profil Risiko berdasarkan Surat Edaran Bank Indonesia (SEBI) No.6/23/DPNP tanggal 31 Mei 2004, yang menetapkan batas maksimal NPL yang kurang dari $(<) 5 \%$, untuk kategori bank sehat 


\section{"Vol 3, No 1 (2019): July - Desember"}

\section{Strategi Pencegahan Non Performing Loan PT. Bank Tabungan Pensiunan Nasional, Tbk Mitra Usaha Rakyat Kantor Cabang Pembantu Tolitoli}

Beberapa strategi utama pencegahaan Non Performing Loan yang dilakukan PT. Bank Tabungan Pensiunan Nasional, Tbk Mitra Usaha Rakyat Kantor Cabang Pembantu Tolitoli selama tahun 2011 sampai dengan 2016 adalah sebagai berikut : (1) Verifikasi calon debitur pemohon kredit usaha secara lebih selektif dan detail dengan menerapkan prinsip kehati-hatian yang tinggi dan menyetujui pemberian fasilitas kredit setelah melalui analisis penilaian 5C. (2) Melaksanakan customer maintenance secara berkala, sehingga bank sesegera mungkin dapat mendeteksi indikasi penurunan usaha debitur dan mempersiapkan antisipasi untuk mencegah terjadinya Non Performing Loan. (3) Menjalankan program Capacity To Growth (C2G), secara berkala/rutin. Program C2G yang dijalankan PT. Bank Tabungan Pensiunan Nasional ,Tbk Mitra Usaha Rakyat Kantor Cabang Pembantu Tolitoli akan membantu menciptakan pengusaha yang cerdas, terampil dan handal. Usaha yang semakin berkembang tentu saja akan mendatangkan penghasilan yang semakin besar sehingga debitur tidak akan mengalami kesulitan keuangan bahkan tidak kesulitan untuk memenuhi kewajibannya kepada bank. Program Capacity To Growth (C2G) yang digalakkan dan dijalankan oleh PT. Bank Tabungan Pensiunan Nasional, Tbk Mitra Usaha Rakyat Kantor Cabang Pembantu Tolitoli inilah yang membedakan bank ini dengan bank-bank umum lainnya yang juga melayani fasilitas kredit usaha

\section{SIMPULAN}

Non Performing Loan PT. Bank Tabungan Pensiunan Nasional, Tbk Mitra Usaha Rakyat Kantor Cabang Pembantu Tolitoli menunjukkan trend yang fluktuatif dari 


\section{"Vol 3, No 1 (2019): July - Desember"}

tahun 2011 sampai dengan 2016. PT. Bank Tabungan Pensiunan Nasional, Tbk Mitra Usaha Rakyat Kantor Cabang Pembantu Tolitoli mengalami peningkatan persentase NPL pada tahun 2012,2014 dan 2015. NPL tahun 2012 sebesar 3,2\%, tahun 2014 sebesar 2,1\% dan tahun 2015 sebesar 2,9\%. Selain itu terjadi juga penurunan persentase NPL pada tahun 2013, dan tahun 2016. Tahun 2013 NPL turun menjadi 1,1\% dan tahun 2016 menjadi 0,2\%. Pengelolaan Non Performing Loan PT. Bank Tabungan Pensiunan Nasional,Tbk Mitra Usaha Rakyat Kantor Cabang Pembantu Tolitoli telah efektif, dibuktikan dengan persentase NPL dari tahun 2011 - 2016 yang kurang dari (<) 5\%, sesuai dengan standar pengukuran efektifnya pengelolaan NPL yaitu NPL kurang dari (<) 5\%, untuk kategori bank sehat, berdasarkan Surat Edaran Bank Indonesia (SEBI) No.6/23/DPNP tanggal 31 Mei 2004, tentang Kriteria Penetapan Peringkat Profil Risiko, dalam suatu lembaga bank.

\section{REFERENSI :}

Abdurrachman. 2001. Ensiklopedia Ekonomi Keuangan dan Perdagangan. Jakarta : Erlangga

Djiwandono Soedradjad. 2014. Menuju Sistem Perbankan Untuk Mendukung Pembangunan, dalam http://kolom.pacific.net.id.ind (Halaman 196), diakses 07 April 2017

Hermansyah. 2011. Hukum Perbankan Nasional Indonesia. Jakarta : PT.Raja Grafindo Persada

Malayu S.P. Hasibuan. 2011. Dasar-Dasar Perbankan. Cetakan Kesembilan, Jakarta : PT. Bumi Aksara

Ismail. 2010, Manajemen Perbankan. Cetakan 1. Jakarta : Prenada Media Group Julius R. Latumaerissa. 2011. Bank dan Lembaga Keuangan Lain. Jakarta : Salemba Empat

Kasmir. 2012. Manajemen Perbankan. Revisi. Jakarta:PT.Raja Grafindo Persada Kasmir. 2014. Bank dan Lembaga Keuangan Lainnya. Revisi - Cetakan - 14. Jakarta : PT. Raja Grafindo Persada 
"Vol 3, No 1 (2019): July - Desember”

Siswanto Sutojo. 2008. Menangani Kredit Bermasalah. Edisi Kedua. Jakarta : PT. Damar Mulia Pustaka

Sigit Triandaru \& Totok Budisantoso. 2012. Bank dan Lembaga Keuangan Lain. Edisi 2. Jakarta : Salemba Empat

Thamrin Abdullah \& Francis Tantri. 2013. Bank dan Lembaga Keuangan. Edisi Pertama cetakan Kedua. Jakarta : PT. Raja Grafindo Persada

Totok Budisantoso \& Nuritomo. 2014. Bank dan Lembaga Keuangan Lain. Jakarta : Salemba Empat

Wiratna Sujarweni. 2014. Metodologi Penelitian. Cetakan Pertama, Yogyakarta : PT. Pustaka Baru Press

Veithzal Rival,dkk. 2013. Credit Management Handbook. Edisi Revisi. Cetakan ketiga. Jakarta : PT. Raja Grafindo Persada 